\title{
Micro-Lectures Used in College English Teaching for the Students Majoring in Arts
}

\author{
Xueqin $\mathrm{Lu}$ \\ School of Foreign Languages \\ Wuhan Textile University \\ Wuhan, China \\ E-mail: luuhee@126.com
}

\begin{abstract}
Micro-lectures bring a new idea to the traditional college English teaching reform. Many students majoring in arts are poor at English and not interested in it. They also lack motive in English learning. Teachers took the college English teaching for them as a tough task, at the same time students regard English learning as a trouble. Both of them hope to step out of the awkward situation. Micro-lectures accord with art students' English learning status, and follow students' artistic taste and modern learning style, help teachers to change their roles in teaching, which provides a way out for both teachers and students.
\end{abstract}

Keywords-micro-lectures; college English; students majoring in arts

\section{INTRODUCTION}

Many students majoring in arts love arts but neglect English. They have a bad common of English and little motive in English learning. They are always pushed by the teachers in learning because of their poor foundation and bad performance. On one hand teachers shoulder the tough task of the college English teaching for students majoring in arts, on the other hand traditional college English teaching can't satisfy those special students' need. Reforming is expecting to motive this special group of students.

\section{DEFINITION OF MiCRO-LECTURES}

Ideas from the Wikipedia is that the term micro-lectures is not used here to refer to micro-content for micro-learning, but to actual instructional content that is formatted for online and mobile learning using a constructive approach. The Chronicle of Higher Education describes micro-lectures as approximately 60 second presentations with a specific structure. David M. Penrose, an independent instructional designer and eLearning consultant, has articulated the process for creating these micro-lectures.

In China it was first defined in the year of 2011. It is a kind of lecture utilizes the micro teaching video as the media. It mainly aims at one point, for example one difficult, important or testing point in one subject or one part of teaching procedure, for example learning activities, theme, experiment and task. It is designed as a situational online video course supporting multiple learning style. It is featured as prominent topic, short and classical content, interactive teaching and diverse resources. Learners can use mobile phone, ipad and other portable devices to learn at anytime and any place. It is a kind of efficient learning by one point at once, because many a little makes a miracle.

\section{PRESENT RESEARCH AT HoME AND ABROAD}

Dr. McGrew at the University of Northern Iowa and Dr. Kee at the University of Leeds held the idea that microlecture was the "one minute lectures". Shea stated that these specific lectures are combined with specific activities designed to promote the epistemic engagement of the learner. In the year of 2012, Educause resource, initiative "7 Things You Should Know About" series. In each issue, the focus addresses seven basic questions: What is it? How does it work? Who's doing it? Why is it significant? What are the downsides? Where is it going? What are the implications for teaching and learning? It systematically explain the microlecture. All the experts think that the interest surrounding of the use of micro-lectures has continued to grow, even outside of the United States, to places like Hong Kong University. Many universities, such as, Princeton University (Humanities Resource Center), Humboldt State University, University of West Florida, and University of Illinois Urbana-Champaign support the importance of an innovative teaching-learning approach for learners in the 21 st century.

But the great impact from the micro-lectures are the systematic ones which are called MOOCs (Massive Open Online Courses). There are the abundant, prominent MOOCs from Khan Academy, TED-Ed, Udacity, Edx and Coursera. MOOCs draw people in different countries to attend. It is convenient, because students all over the world can apply for the courses they want to learn without traveling. Those courses are really appealing, because many of them are delivered by the famous professors from the prominent universities such as Harvard University and MIT(Massachusetts Institute of Technology).

In China many experts and teachers do some research of micro-lectures, such as, Jiao Jianli, Li Jiahou, Hu Tiesheng. Some of them narrate their own understanding for the definition of micro-lectures, others make further research and definite the micro-lecture again by themselves, the others unfold the its prospect. Meanwhile all those hold an idea that 
micro-lecture is an efficient resource for learning because of its focused delivery of topics, cutting-edge updating of knowledge, careful management, diversity style, replaying for consolidation and easy manipulating.

\section{LEARNING StATUS OF STUDENTS MAJORING IN ARTS}

As we all know arts lay in every aspect in our life. It covers as broadly as our eyes can. It is a kind of carrier of culture without any transmission. In fact, it can transmit from the old to new times and cross the south to the north by itself. Students majoring in arts love arts and are familiar with this feature. They think arts can develop independently without any help of transmission. Even in the foreign art exchange, arts can speak by themselves. So students majoring in arts show low acceptance for English.

Vividness and beauty are two characteristics of the arts. This criterion binds those students' mind. They are used to intuitive and imaginative thinking. They are emotional, romantic and creative who love being unique and showing themselves. In language acquisition, they also pursue the same fun and taste. However, traditional college English teaching just neglect those students' characteristics. It is a procedure of routine teaching, which is fixed, cramming and tedious.

How do those students think of the course of college English? Do them show interest in English? This paper employs the questionnaire and interview to know their learning status. We delivered the survey in a university at seven different classes among 240 students majoring in arts including fashion design, art design and media design. The questionnaire are aimed at learning motive, course content and learning time. We got 240 sheets and chose 199 valid sheets to calculate and analyze.

First students were asked by the question- "Do you love the course---college English? Or are you interested in English?" 52 percent students showed interest in English and had drive for English learning. 18 percent students just hold a neutral attitude. By interview we knew some of them took college English as a compulsory course they had chose and they had to learn. English learning was not interesting enough, but they didn't hate it. The rest of 30 percent students answered clearly that they showed no interest in English learning. When we researched further those 30 percent students we found 40 percent of them showed no interest in English. 48 percent of them thought that their poor command of English prevented them from studying further.

Second students were asked by the multiple questions"Do you think it is necessary to learn college English at university?" and "If you answer 'Yes', what are your reasons?" To our surprise 95 percent students thought it was necessary and important to learn college English. When we studied further, we got the reasons. 69 percent students thought English would be useful in the future job. 48 percent students thought English was essential for the cross-cultural communication. 32 percent students thought English was beneficial for their studying abroad plan. 18 percent students thought English was helpful for the entrance examination for postgraduate school. Only 5 percent students thought English was unnecessary and unimportant, because they wouldn't study further or go abroad.

From the above statistics we can conclude that most of students majoring in arts held an idea that English is important for many purposes. But only a little more than half of them show interest in English and have drive in English learning. With poor command of English and lack of motive, students won't study by themselves. Students are always pushed by teachers. And teachers take English teaching as tough task. Both of them step difficultly. How to arouse students' interest and how to help them study step by step to gain the confidence? Micro-lectures will be helpful.

\section{MicRO-LECTURES AND COLLEGE ENGLISH TEACHING FOR THE STUDENTS MAJORING IN ARTS}

\section{A. Micro-lectures Accord with Art Students' English Learning Status}

John Sweller's cognitive load theory points out that traditional class teaching employs same teaching content and arranges the same activities, which gives the top students low cognitive load and waste the teaching. However, the under average students suffer too much cognitive load and can't move further. From the above statistics, we know 48 percent of the students who show little interest in English because they have a poor command of English. Micro-lectures enable students at different levels can choose their learning resource and arrange their learning time, which won't affect others' learning steps. Thus top students can enjoy the abundant resource and arrange their learning flexibly. While under average students can watch the video repeatedly and won't neglect the key point. They won't be bothered by their poor foundation and won't bear the pressure from the excellent students. Gradually gaining confidence, those students who have a bad common of English will show interest in English. Only by this means, we can realize the stratified teaching and students can enjoy individualized learning.

Benjamin Bloom's mastery learning theory proves that all the learners can achieve a good mark if they are given enough time and offered best teaching. From the above statistics 95 percent students think English is useful and essential. With this beneficial belief, if teachers make some changes in college English teaching, students must work hard and gain progress. Students won't be nervous as the former traditional classroom teaching. Because they won't face the teachers and classmates, they just face the microlectures. The Educause discussed "The abbreviated format of micro-lectures can be highly effective by focusing students' attention on a single topic for a short time, limiting the opportunities for distraction." It will be helpful for the art students who are good at imaginative thinking. Microlectures can be replayed as students want until them understand. If there are still some problems for students, they can bring them to the class for discussion. What's more, the learning won't be restricted in the class at the fixed time. They can learn by their pace and arrangement. During the learning, each achievement will encourage the under average student go further and make them confident. 
Stephen Krashen's Input Hypothesis advocates “i+1” model. It points out that each input should be a little beyond the learner's acquired knowledge. Only by this way, acquisition and learning work. Micro-lectures are the " 1 " because of their prominent topics, short and classical content. Also as the Educause discussed "A micro-lecture can focus on a single important point, providing a self-study opportunity for fundamental concepts and those that are difficult to understand." By multipling those small points students can step one by one and go further.

\section{B. Micro-Lectures Follow Students' Artistic Taste and Modern Learning Style}

From the above discussion, we know students majoring in arts are emotional, romantic, creative and unique. They are used to intuitive and imaginative thinking and pursue romance and beauty. They depend much on sensibility. They show low acceptance for English and little interest in the traditional college English teaching. Micro-lectures are featured as prominent topic, short and classical content, interactive teaching and diverse resources. It is favored as impressionistic learning, iconic learning. In the microlectures, we can use pictures, music and video to draw students' sight and hearing to match their art taste. In the unconscious influence, students appreciate and learn. Microlectures in college English teaching from different units and topics display with different methods will definitely avoid tediousness. By this means teachers can easily arouse students' interests. Nowadays with the development of the information technology, students get many accesses to the knowledge. They can easily get knowledge or information which they are interested in at anytime and any place with the help of the communication products. This learning style is appealing for those young people. Since students' learning style has changed, teachers should also change their teaching model to follow students in order to arouse students' interest. Micro-lectures realize students' modern learning style. Because they can use mobile phone, ipad and other portable devices to learn micro-lectures at any place and any time.

\section{Micro-Lectures Provide Teachers a Way Out}

In the year of 2005 American scholars Koehler and Mishra emphasized the importance of technological content knowledge and advocated the technological pedagogical and content knowledge (TPACK), which is widely accepted by the worldwide academic community. According to the research from Xia Jimei, tough task of teaching and deficient chances for development are the two barriers to teachers' personal development, which easily lead to the job burnout. Technologies used in micro-lectures change teacher's role. On one hand teachers turn to be the guide on the side from the sage on the stage, on the other hand micro-lectures provide teachers with a stage to learn not only the technology but also the teaching content which will promote their professional skills.

\section{CONCLUSION}

From the above discussion we can conclude microlectures focus on delivery of topics, show cutting-edge updating of knowledge, and provide insight, vision and careful management for students. They can be replayed for consolidation. It follows the principle of fragmentation of knowledge and fragmentation of learning. Micro-lectures follow students' knowledge construction law, and help individualized learning. Students majoring in arts are a special group, who love arts and neglect English because they think arts can be transmitted without any help. They show low interest in English learning but at the same time they think English is important. Micro-lectures will arouse students interest and help them study English intiatively. Because it follows students' artistic taste and modern learning style, accords with art students' English learning status. It also help teachers to be skillful with the modern technology, change their role in teaching and promote their self-development.

\section{ACKNOWLEDGMENT}

I thank Zhang Hong for the opportunity of lectures of micro-lecture addressed by the Foreign Language Teaching and Research Press, which gave me a chance to get to know micro-lectures and enlightened me. I thank my colleagues Yang Xue and $\mathrm{Yu}$ Yan who helped me to deliver the questionnaires and collected them on time. I also thank my family who support me to finish this paper.

\section{REFERENCES}

[1] Asha Kanwar. Old Wine in New Bottles? Exploring MOOCs [DB/OL]. 2014 http://www.col.org/resources/speeches/2014presentations/Pages/2014 -03-28.aspx..

[2] British Council. Platform provided for the British Council's First Ever MOOCs [N].
[ http://www.britishcouncil.org/organisation/press/platform-britishcouncil's-first-ever-moocs.2013.

[3] Chen Bingbin. MOOCs: Contributions and Dilemmas. [J] Computerassisted Foreignlanguage Education, 2014(5):38 43(in Chinese)

[4] Crosslin, M. Microlectures: A Constructivist's Dream Come True. $\begin{array}{ccc}\text { EduGeek } & \text { Journal } & \text { from }\end{array}$ http://www.edugeekjournal.com/2009/03/04/microlectures-aconstructivists-dream-come-true/

[5] EDUCAUSE. 7 Things You Should Know About MICROLECTURES. Retrieved on November 2, 2012 from http://www-cdn.educause.edu/ir/library/pdf/ELI7090.pdf

[6] Fini, Antonio. The Technological Dimension of a Massive Open Online Course: the Case of the CCK08 Course Tools. [J] International Review of Research in Open and Distance Learning, 2009 (10) : 1-26

[7] Guan Zhongke. Microlecture. [J] Chinese Journal of information technology, 2011(17):14 (in Chinese)

[8] Hu Tiesheng, Zhou Xiaoqing. Current Situation Analysis and Development Strategies of the Micro-lecture Construction in Universities. [J] Modern Educational Technology, 2014(5):5 13 (in Chinese)

[9] Jeffrey R. Young. Beyond the MOOC Hype: A Guide to Higher Education's High-Tech Disruption [M] 2013 Kindle version.

[10] Jiao Jianli. Microlecture and Its Application and Influence. [J]Educational Technology for Primary and Secondary Education, 2013 (4) : 13 14 (in Chinese)

[11] Kee, T.P.. The one minute lecture. [J] Education in Chemistry, 1995 32: $100-101$ 
[12] Li Jiahou. Definition and Development of Microlecture. [J] Educational Technology for Primary and Secondary Education, 2013 (4) : 10 12(in Chinese)

[13] Lei Dan, Liu Huani. On Foreign Language Teacher's Role and Niche. [J]Modern Educational Technology, 2015 (3) : 59 64 (in Chinese)

[14] Ma Wulin, Hu Jiasheng. on the Impact of International MOOCs and Redesign of College English Curriculim. [J] Computer-assisted Foreignlanguage Education, 2014 (5) : 48 54 (in Chinese)

[15] McGrew, L. A. A 60-second course in Organic Chemistry. [J]Journal of Chemistry Education, 199370 (7): 543-544

[16] Morris, L.V. "Little Lectures?". [J] Innovative Higher Education, 200934 (2): 67-68.

[17] Shea, P., Bidjerano, T. Community of inquiry as a theoretical framework to foster "epistemic engagement" and "cognitive presence" in online education. [J] Computers and Education, 200952 (3): 543-553.

[18] Shieh, David. These lectures are gone in 60 seconds. Chronicle of Higher Education, 200955 (26), A1, A13.

[19] Stephen Haggard. The Maturing of the MOOC: literature review of massive open online courses and other forms of online distance learning[DB/OL].

http://www.gov.uk/government/uploads/system/uploads/attachment_d ata/file/240193/13-1173-maturing-of-the-mooc.pdf.september20,2013.

[20] Wikipedia. Micrilecture [EB/OL]. 2014 from http://en.wikipedia.org/wiki/microlecture.

[21] Xia Jimei. Concerns about college EFL teachers' professional development problems and way-out in the New Chinese Context (in Chinese) 2012 (2) 6-8. 